\title{
Digital Nursing Technology to Achieve Job Satisfaction: A Systematic Review
}

\author{
Diah Arruum ${ }^{1,2}$, S. Setyowati ${ }^{1 *}$ (D), Hanny Handiyani ${ }^{1}$, Raldi Artono Koestoer ${ }^{3}$ \\ ${ }^{1}$ Faculty of Nursing, Universitas Indonesia, Depok, Indonesia; ${ }^{2}$ Faculty of Nursing, Universitas Sumatera Utara, Medan, \\ Indonesia; ${ }^{3}$ Faculty of Engineering, Universitas Indonesia, Depok, Indonesia
}

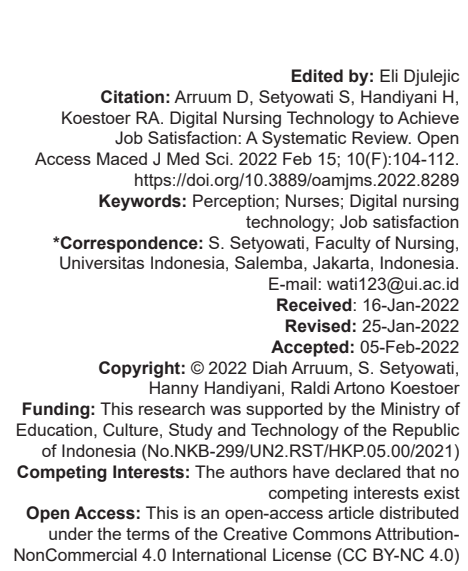

Introduction

Health care has changed rapidly with the introduction of Health Information Technology (HIT) [1], [2], such as the use of Electronic Health Record (EHR) and different Electronic Health (E-Health) devices that have positively influenced the daily practice of health professionals and the way of delivery. It is generally assumed that HIT increases the safety and quality of health care and also reduces morbidity and mortality [3].

In the $21^{\text {st }}$ century, nurses faced the challenges of exhibiting competent information technology skills. Nursing informatics and the use of information technology are essential components that support modern nurses' jobs. However, there are limited studies that provide comprehensive data on the impact of Information and Communication Technologies (ICTs) on nursing care [4]. Previous studies showed that nurses perceive ICTs positively because of improvements in accuracy, patient safety, and ease of access [5].

Previous study on the negative perceptions of the impacts of technology showed that nurses usually prioritize the troubleshooting of equipment due to device malfunctions that interrupted health care [6]. According to Kiekkas et al, nurses sometimes felt that technology increased stress and moved the focal point away from patients [7]. However, most of the job problems are due to excessive workload based on the work-related and situation-specific syndrome, which is usually characterized by emotional exhaustion and depersonalization that reduces work efficiency [8].

Dyrbye et al. also stated that burnout lowers job performance among nurses [9], patient satisfaction [10], incomplete health care [11], and poorer outcomes such as higher mortality rates [12]. Therefore, efforts to improve burnout needs to focus on contextspecific work system factors since it is associated with inefficient work progress, excessive workloads, inadequate rewards and staffing, values conflicts, and a poor working environment [9], [13], [14]. Similarly, an increase in the use and dependence on technology for nursing produced the largest professional healthcare workforce. This showed that more literature review needs to be carried out to explore some studies in digital nursing technology and its impact on burnout to achieve job satisfaction. 


\section{Methods}

\section{Study design}

This study used a systematic review method, where the articles were obtained on the scientific databases, namely PubMed, PubMed Central, Science Direct, Scopus, and Web of Sciences, that were published from 2019 to 2021. The analysis of the Preferred Reporting Items was carried out for Systematic Reviews and Meta-Analyses (PRISMA). Meanwhile, ethical considerations such as respecting principles based on The Belmont Report which consists of beneficence, respect for human dignity, and justice have been conducted and approved by the ethical committee, Faculty of Nursing University, Indonesia (N0:215/UN2.F12.D1.2.1/PPM.00.02/2021).

\section{Search strategy}

The search equations used were 'Nurses' perception in using digital technology" OR "digital sensor" AND "increasing early detection deteriorate on patients" OR "to detection healthcare-associated infections" OR "advantages of nursing" OR "nursing benefits" AND "Using Digital Technology" OR "digital sensors" AND "detection Device Associated Infections, An Issue of Infectious Disease Clinics" AND "Job Satisfaction of Nurses" OR "Nurses Satisfaction."

\section{Selection of studies}

The inclusion criteria in this study were nurses, nurse job satisfaction or satisfaction, early detection in preventing patient deterioration, healthcare professionals, monitoring of vital signs, technology in nursing, digital technology, digital sensors, nurses' perceptions of the use of technology positively or negatively, awareness in the use of technology, and the workload in the use of technology. Furthermore, an extraction process was carried out on 17 full-text articles for eligibility assessment.

\section{Results}

\section{Type of studies}

After assessing the 312 articles and 11 duplicates through the PRISMA process, two articles were removed from the selected 19 articles. This is because they are related to monitoring the development of technology use and not on nurses who apply technology, therefore, only 17 articles were used in this study (Figure 1). Moreover, this study is based on nurses' satisfaction in the use of digital technology such as digital sensors and computer information.
Effects of Using Digital Technology in Achieving Nurse Job Satisfaction

In this study, the results showed that there are still differences in achieving nurses' job satisfaction in the application of digital technology. Out of 17 articles, it was discovered that the use of technology has an overall positive impact on nurses, some have a positive or negative impact. Meanwhile, other articles stated that technology has a negative influence in providing services to patients directly or using remote applications (Table 1).

Furthermore, six articles were discovered to have a positive impact, where the use of digital technology is perceived positively and provides benefits for nurses by improving the relationship or nursepatient interactions [15], [16]. Although communication technology is not yet fully accurate, it has the potential to manage and empower the long-term health conditions of patients and healthcare professionals [15]. Similarly, nurses show a positive attitude towards the use of health technology, where the use of technological devices provides opportunities for better health care [17], Nurses also realize that providing care for patients through technology is a form of caring competence [18].

According to other studies, technologies such as sensors have the effectiveness of continuously monitoring vital signs that can be used to improve clinical outcomes in the inpatient setting [16]. Redeker also stated that the use of electronic sensors for nurses is applicable for collecting, recording, transmitting data in real-time, remote monitoring, self-monitoring, and communication between health professionals and patients [15]. Furthermore, some studies supported technology positively, where almost all nurses as Directors of Nursing or team leaders have experience in using Digital Nursing Technologies, specifically with information and communication technology (ICT). This makes task completion easier with better healthcare, reduced physical burden, and mental stress, and also includes nurses in the development and testing of digital technology [19]. Technology has a positive view because it saves time when information about patients is needed and increases efficiency [19], [20]. Fadel et al. also stated that technology increases nurses' job satisfaction and reduces documentation [20].

Moreover, six articles were perceived as positive and negative by nurses, where the use of electronic devices in the patient's bed makes nurses spend longer time providing various care to patients. They also simultaneously document bedside care, however, many nurses were not satisfied due to duplication of work and increased workload. In addition, they also recorded injuries related to posture and duration of time required to complete electronic forms on bedside touch screens, and negative comments contradicted by observational data [21]. Similarly, the statement by Leenan et al. that there is still dissatisfaction in the use of electronic devices such as alarms due to 


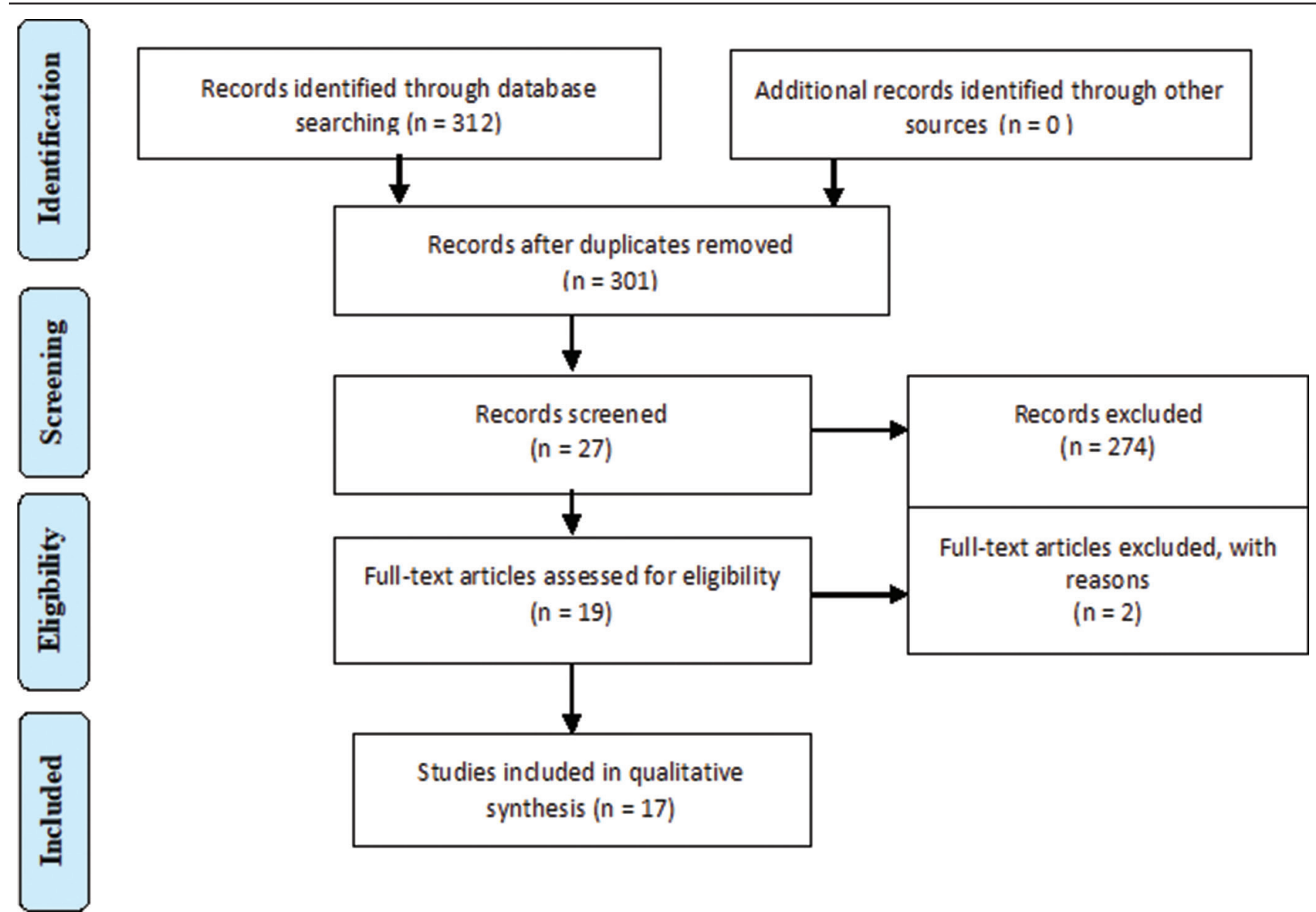

Figure 1: Preferred reporting items was carried out for systematic reviews and meta-analyses analysis

system malfunctions, alarm frequency and dissonance with nurse measurements [22], and also found the low acceptance in the implementation of information systems, lack of training and support as inhibiting factors [23], [24]. However, positive perceptions are found in the use of management information systems and alarms, where electronic systems are very useful and easy to be used by nurses since they are efficient in storing patient data [22], [23].

Based on the results of other studies, the use of ViSi Mobile (VM) and HealthPatch mostly has a positive effect on nurses or health workers for continuous and early monitoring of vital signs for quick intervention. However, there are also negative effects due to battery resistance, irrelevant or false alarms that make nurses get tired and increase workload due to excess data [25]. It was shown that the use of smartphones can improve technical competence, work performance, nurse-patient relationships, have all information about patients, save time between fulfilling care to patients, and electronic documentation, including for patient safety in medication errors. The negative perception is related to technological interference, causing a scheduled downtime and the difficulty in the use of smartphones in elderly patients [26]. Moreover, other conditions also affect nurses' job satisfaction, specifically when technology has a negative impact.
In this study, five articles were perceived as negative, and one of them is from HIT application which stated that HIT used by nurses is not user-friendly, time-consuming, and unsupportive in daily professional practice. It also showed that HIT is stressful, unpleasant, lacks knowledge, gets inadequate training, therefore, nurses feel incompetent, delay, or avoid using HIT [27]. In addition, the use of technology can decrease due to unclear communication between nurses and the development team in designing tools for detection such as falls and urinary tract infections, which changes the workflow of nursing care over time. This also means that not all nurses who use smartphones get an alarm text and have the time to check incoming email [28]. The application of HER in nurses is currently still in low acceptance due to fatigue caused by the excessive use of technology [29]. The negative results were discovered in other articles, where nurses are not ready for a digital future and do not feel that as leaders in digital technology decision-making through the use of cellphones and the internet and cannot facilitate digital literacy or professionalism models [30]. It was also discovered that the use of Patient Accessible Electronic Health Records (PAEHR) Technology has great advantages, however, it affects the nurses' working environment. This creates new problems and concerns that they cannot answer patient questions because nurses act as contacts. Since the first factor 
Table 1: Digital nursing technology to achieve job satisfaction: A systematic review

\begin{tabular}{|c|c|c|c|c|c|}
\hline Author/Year/Topic & Study Desain & Setting & Sample & Measurement & Results \\
\hline $\begin{array}{l}\text { Gance-Cleveland et al., (2020) } \\
\text { Aurora, Pennsylvania, Amherst. Use } \\
\text { of theory to guide development and } \\
\text { application of sensor technologies } \\
\text { in Nursing. } \\
\text { https://doi.org/10.1016/j.outlook. } \\
2020.04 .007\end{array}$ & $\begin{array}{l}\text { The development } \\
\text { of the theory }\end{array}$ & $\begin{array}{l}\text { Presentations at } \\
\text { the Council for the } \\
\text { Advancement of } \\
\text { Nursing Science } \\
2019 \text { Advanced } \\
\text { Methods Conference } \\
\text { on Expanding } \\
\text { Science of Sensor } \\
\text { Technology in Study. }\end{array}$ & Three nurse scientists & $\begin{array}{l}\text { Paradigm and a } \\
\text { study by nurse } \\
\text { scientists on the } \\
\text { sensor technology } \\
\text { used for health } \\
\text { services. }\end{array}$ & $\begin{array}{l}\text { Based on the statements of several scientists in the } \\
\text { world who discussed the limits of nurses' involvement } \\
\text { in sensor technology, it was discovered that nurses } \\
\text { have the opportunity to provide health services. The } \\
\text { relationship between nurse and patient is affectionate } \\
\text { through technology, however, it is not used during } \\
\text { interaction. Since nurses are scientists, they can explain } \\
\text { the development, implementation, and evaluation of using } \\
\text { technology based on theories. }\end{array}$ \\
\hline $\begin{array}{l}\text { Redeker, (2020) West Haven } \\
\text { Sensor technology for nursing study. } \\
\text { https://doi.org/10.1016/j.outlook. } \\
\text { 2020.03.009 }\end{array}$ & The review reports & $\begin{array}{l}\text { Presentation from } \\
\text { the Expanding } \\
\text { Science of Sensor } \\
\text { Technology in } \\
\text { Nursing Study } \\
\text { Conference } \\
\text { presented by }\end{array}$ & Nurses & Nurses' perception & $\begin{array}{l}\text { The collection, recording, and transmission of data can } \\
\text { generate real-time data through electronic sensors, } \\
\text { where they are processed through remote monitoring, } \\
\text { self-monitoring, and communication between healthcare } \\
\text { professionals and patients. Sensor technology is also } \\
\text { useful for the analysis and interpretation of data. }\end{array}$ \\
\hline
\end{tabular}

\section{Randomized 2019 \\ controlled trial \\ 20 nurses 60 patients, 3 physician assistants, and 6 medical doctors} Continuous Monitoring of Vital Signs in the General Ward Using Wearable Devices: Randomized Controlled Trial.
Weenk et al., (2020) Netherlands doi: 10.2196/15471
This study aims to identify positive and negative effects as well as barriers and facilitators for the use of two wearable devices.

$\begin{array}{lll}\text { An explanatory } & \text { In healthcare } & 1,335 \text { Director of } \\ \text { sequential mixed } & \text { environment } & \text { Nursing through an } \\ \text { methods design } & & \text { online survey and 14 } \\ & & \text { Director of Nursing } \\ & \text { through Focus Group } \\ & & \text { (FGs). }\end{array}$

Explore nurses' perspectives and experiences. https://doi.org/10.1016/j.zefq. 2020.10.010

Seibert et al., (2020) Germany Application of digital technologies in nursing practice: Results of a mixed methods study on nurses' experiences, needs, and perspectives.

Mather et al., (2019)

Australia

Nurses as Stakeholders in the

Adoption of Mobile Technology

in Australian Health Care

Environments: Interview Study. doi: $10.2196 / 1427$

\section{Bail et al., (2020)}

Australia

Implementation pilot of a novel mixed-methods case study. https://doi.org/10.1071/AH18231 electronic bedside nursing chart: a

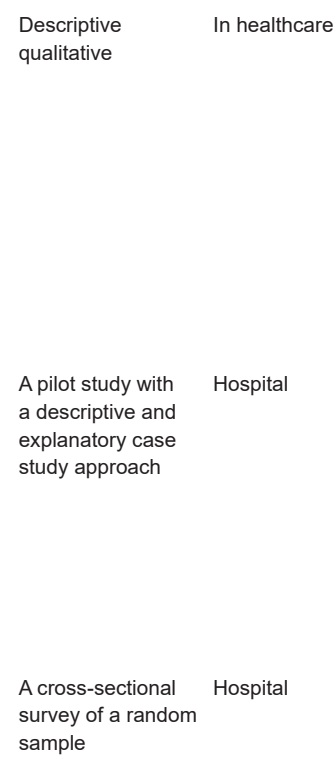

A pilot study with
a descriptive and a descriptive and
explanatory case study approach

Hospital

A cross-sectional Hospital survey of a random sample

The study used two sensor devices called ViSi Mobile (VM) and Health Patch (HP) in form of sensor devices for vital sign monitoring that are sent by using a mobile phone to send vital sign data to mobile devices through Bluetooth. The results obtained some positive perceptions, namely the use of sensor devices to continuously monitor vital signs, early detection for quick intervention, save time, reduce the length of stay at hospital, workload, have a feeling of security for patients. The negative perceptions were discovered due to continuous monitoring of data or excess information, conditions in the room such as the ICU, hence, the alarms/sensors installed led to disruption of time quality due to false-positive alarms, irrelevant, and fatigue (leading to false-positive alarms). However, the use of the device cannot detect pain.

The results showed that $95 \%$ of nursing directors have experience and perception in digital nursing technology such as information and communication technology. Therefore, through the use of technology, the tasks become easier, time-efficient, and improve nursing quality. It is rare to obtain a negative perception of technology, making it to overcome the problem of mental stress and physical burden. This is because negative effects or concerns are becoming less. The results of the FGs showed that nurses needed technology for participatory development and were involved in the development and testing of digital technology. The study focused on nurses as stakeholders, moreover, the contributing factors include actions, work-around, concerns, experiences, attitudes, and influences that impact thinking about access and use of technology. Also, nurses are not ready to provide digital health services in the future. This is because nurses have not realized that they are the front-line leaders in decision-making. In addition, they are also cannot facilitate digital literacy or professionalism models.

This study was to understand and investigate the implementation of novel bed electronics and the factors influencing the impact of nurse applications and

workflows

Melnick et al., (2021)

USA

electronic health

record usability and professional

burnout among US nurses.

doi: 10.1093/jamia/ocab059
The result showed that since the installation of the novel electronic in the patient's bed, the implementation of missed-care to patients has decreased, and the average time spent at the bedside increases from 21 to 28 minutes for 1 hour. In a qualitative study, it was discovered that there are (1) inconsistent expectations, (2) decision conflicts between managers and nurses, and (3) workflow effects (digital interface ergonomic settings). The study also applied the effects of technology to support nursing, shared understanding of the purpose of technology, and the scope of the project in nursing care. Nurses' perception about the use of Health Electronic Record (HER) based on the SUS assessment score is still in low marginal acceptance, which is $24 \%$, due to fatigue. HER usability was measured with the System Usability Scale (SUS, range 0-100).
8638 nurses had completed the survey

This study measured nurse-Perceived Electronic Health Records (EHR) usability of technology and evaluated professional professional
burnout of nurses. 
Table 1: (Continued)

\begin{tabular}{l}
\hline Author/Year/Topic \\
\hline Fadel et al., (2020). \\
Benghazi City \\
An Evaluation of the Attitudes of \\
Healthcare Nurses Towards New \\
Technologies. \\
https://doi. \\
org/10.1145/3410352.3410731 \\
Jahnke et al., (2021) \\
The United States. \\
Social practices of nurse care \\
coordination using sensor \\
technologies- Challenges with an \\
alert system adoption in assisted \\
living communities for older adults. \\
https://doi.org/10.1016/j.ijnss. \\
2021.05.011
\end{tabular}

\begin{tabular}{lll} 
Study Desain & Setting & Sample \\
\hline $\begin{array}{l}\text { A cross-sectional } \\
\text { descriptive study }\end{array}$ & Healthcare facilities & $\begin{array}{l}\text { Nurses in healthcare } \\
\text { facilities. }\end{array}$
\end{tabular}
acilities.

A qualitative study Social practice

Nursing staff and socia workers as users, through five user interviews and focus groups with six system developers.

London

Implementation of Wearable Sensors and Digital Alerting Systems in Secondary Care: Protocol for a Real-World Prospective Study Evaluating Clinical Outcomes. doi: $10.2196 / 26240$

De Leeuw et al., (2020) Netherlands Face-to-face Identification of Factors Influencing semi-structured the Adoption of Health Information interviews Technology by Nurses Who Are Digitally Lagging: In-Depth Interview Study.

Burkoski et al., (2019)

Toronto, ON.

Experiences of Nurses Working

in a Fully Digital Hospital: A

Phenomenological Study.

Moll and Cajander, (2020)

Sweden

On Patient Accessible Electronic

Health Records and the

Experienced Effect on the Work

Environment of Nurses.

doi: 10.3233/SHTI200316

\section{Bisrat et al., (2021)}

Ethiopia

Implementation challenges and

perception of care providers on

Electronic Medical Records at

St. Paul's and Ayder Hospitals,

Ethiopia.

https://doi.org/10.1186/

s12911-021-01670-z

\section{A descriptive and cross-sectional}

Phenomenologi-cal 8 Nurses methodology

Emergency room, 200 nurses intensive care, service department

Inpatient

Data were gathered through interviews

Data were gathered through in-depth semi-structured interviews.

Data were gathered through an interview study.

The study reports Five Nurses on preliminary

240 health care providers. An interview was conducted with a total of 10 persons. The majority of the respondents were nurses. quantitative and qualitative methods

Measurement

This study evaluated nurses' attitudes towards the use of new technologies in nursing practice.

This study analyzed the gap between creators' intention and the users' implementation (nursing staff and social workers) of an alert system in assisted living communities.

This study was conducted to health technologies of technology. Technology can improve the quality of care by nurses and their thoughts on technology.

This study explored the experiences and needs of nurses with technology.

The study was to achieve a deeper understanding of the experiences of nurses.

The study was to determine the experience of nurses when Patient Accessible Electronic Health Records (PAEHR) was Introduced.

This study to assess the status perceptions, especially on the ease of system, and also , the interest of service providers that involved in the facilitators and design, implementation, and system stages. The negative barriers, while at the same time examine the perception of health care providers at Ayder and St. Paul's Bisrat et al. teaching hospitals. To determine feasibility, in terms perspectives of nurses regarding vital sign monitoring of acceptability and in the nursing ward. It is useful, easy to use but difficult system fidelity, of to be learnt, and dissatisfied for nurses. For instance, continuous vital sometimes they receiving alarms from all patients on the signs monitoring on nursing ward, too annoying, oftenly without clear picture a general ward. of breathing and heart rate, and frequency of alarm malfunctions. 
Table 1: (Continued)

\begin{tabular}{|c|c|c|c|c|c|}
\hline Author/Year/Topic & Study Desain & Setting & Sample & Measurement & Results \\
\hline $\begin{array}{l}\text { Ngugi et al., (2021) } \\
\text { Kenya } \\
\text { Users' perception on factors } \\
\text { contributing to Electronic Medical } \\
\text { Records systems use: A focus } \\
\text { group discussion study in } \\
\text { healthcare facilities setting in Kenya } \\
\text { Philomena. } \\
\text { https://doi.org/10.1186/ } \\
\text { s12911-021-01737-x }\end{array}$ & $\begin{array}{l}\text { Focus group } \\
\text { discussions study }\end{array}$ & Hospital & $\begin{array}{l}20 \text { healtcare } \\
\text { professionals, including } \\
\text { of nurses }\end{array}$ & $\begin{array}{l}\text { This study was to } \\
\text { explore end users' } \\
\text { perceptions and } \\
\text { experiences on } \\
\text { factors facilitating } \\
\text { and hindering } \\
\text { EMRs use in } \\
\text { healthcare facilities }\end{array}$ & $\begin{array}{l}\text { Users' perception that EMR systems is easiness of use } \\
\text { and learning of the system complemented, efficiency } \\
\text { in patient data management, responsive Information } \\
\text { Technology (IT) and collegial support, and user training. } \\
\text { The identifed barriers included: frequent power blackouts, } \\
\text { inadequate computers, lack of continuous training and } \\
\text { delayed IT support. }\end{array}$ \\
\hline $\begin{array}{l}\text { Nakano et al., (2021) } \\
\text { Japan } \\
\text { Perceptions of nurse managers and } \\
\text { staff nurses regarding Technological } \\
\text { Competency as Caring in Nursing } \\
\text { theory in general hospitals in Japan. } \\
\text { https://doi.org/10.33546/bnj. } 1767\end{array}$ & $\begin{array}{l}\text { A cross-sectional } \\
\text { survey design }\end{array}$ & General hospital & $\begin{array}{l}\text { Nurse manager and } \\
\text { staff nurses }\end{array}$ & $\begin{array}{l}\text { This study aimed } \\
\text { to determine } \\
\text { managers' and staff } \\
\text { nurses' perceptions } \\
\text { regarding the } \\
\text { Technological } \\
\text { Competency as } \\
\text { Caring in Nursing } \\
\text { (TCCN) theory }\end{array}$ & $\begin{array}{l}\text { This study showed that nurses' aware that technology } \\
\text { as caring. The nurse managers were more aware of } \\
\text { providing care using technology, and recognizing the } \\
\text { patient needs through technology. }\end{array}$ \\
\hline
\end{tabular}

is with patients, limiting nurses to documenting medical records has led to inaccurate dissemination of important information [31].

\section{Various Types of Technology Applied by Nurses}

This study discovered that there were 10 articles on ICT in nursing services such as the use of EHR[23],[24],[29]. Italsoincludes HIT, ICTorimplementing E-Health, and PAEHR [27], [19], [26], [20], [31], implementation of a novel electronic bedside nursing chart [21], while digital technology is also related to technology [30].

There are 5 articles on the use of sensors, that stated sensor technology in nursing needs to be developed as a tool for intelligence, innovation, and the use of the Internet of things (IoT) to improve health services and studies [17], [15]. Sensor is also a digital alert system that implemented in wards to detect or monitor vital signs of patients [16], [22]. Sensors can also be implemented as a warning system in the living community for adults groups to assist nurses in providing health services [28]. Meanwhile, there are also other articles related to the use of sensors and information technology [25]. There is also article related to the use of technology in general [18].

\section{Discussion}

The continuous development in technology has become an important need in providing services and needs for nurses. Based on this study, there are still gaps in the implementation of technology among nurses due to its impact on job satisfaction. Meanwhile, job satisfaction is a positive feeling of employees about themselves and their duties, which gives happiness or enjoyment at work [32], [33]. Bolli and Pusterla stated that there are four aspects in technology development that affect staff job satisfaction, namely the aspects of change in time use, new activities, access to information, communication tools [34]. Similarly, the digitalization of technology has a positive effect on job satisfaction due to increased staff autonomy, flexible forms of work, productivity, and also create interaction with colleagues and supervisors [34]. Previous study by Fadel et al. also stated that technology increased nurse job satisfaction [20].

This is supported by study on the positive impact of technology, where the development in technology improved nurse-patient interaction [35], [36]. Therefore, nurses become more productive and experienced in overcoming distance barriers to communication [35]. The use of technological devices provides convenience [36], moreover, devices such as sensors also have positive benefits by monitoring the patient's vital signs continuously [16], and transmitting data in real-time as well as remote monitoring [15]. The results of other studies that support technology through ICT facilitate task completion, quality of care, reduce the physical burden and mental stress[19], and save nurses time in seeking information about patients [19], [20].

Previous results showed that there are still negative effects for nurses, where study on HIT applications discovered that nurses were unfriendly, unsupportive in daily professional practice, stressful, and unpleasant [27]. This is in line with study by Melnick et al., where the use of EHR in nurses is currently in low acceptance due to fatigue caused by excessive use of technology [29]. Some searches from the results of these studies still found gaps between nurses in applying technology so that nurses' job dissatisfaction was still found which was influenced by various factors.

Meanwhile, it was discovered that there are still differences in the results of the study related to various technology implementations. Based on study on job satisfaction and technology, nurses were more inclined to innovation, inclusiveness, willingness, and more satisfied with their duties when empowered by leaders [37]. Out of 144 articles, leadership characteristics and cohesion was discovered helpful for leaders to determine organizational strategies and create sustainable innovation [38]. In addition, the caring leaders will encourage their staff's emotional feelings 
in dealing with situations in work environment so they have positive impact, improve innovation, creativity, and give influence on staff that create trust [39], therefore, innovative leaders are needed by nurses to achieve job satisfaction.

Innovation in an organization that is effectively managed can provide job satisfaction and improve service quality. Currently, the demand for digital technology continues to increase, therefore, various products, processes, markets, and innovations have the potential to improve performance [40]. The results of other studies on job satisfaction showed that there is an innovative and motivating relationship with organizational performance, where an increase in achievement can also increase effectiveness, efficiency, productivity, and competitiveness in the digital era [41]. In nursing, digital technology is intended to support healthcare that is Accepted, Effective, and Efficient [42]. This showed that innovations such as digital technology in nursing are important because they improve performance and job satisfaction that influence acceptance of the use of technology.

\section{Limitations}

The limitation of systematic review for researchers is rarely to find the recent published articles related to nurse job satisfaction in the using of technology, especially in implementation of digital sensors for inpatients. Another limitation is that a combination of various databases is still needed to get more optimal results, that is why the further studies are needed.

\section{Conclusion}

The nurses have a positive response because technology makes the completion of work easier, maintains patient safety where it can affect job satisfaction, while negative perceptions are the basis for solving problems. Therefore, support from their leader is needed to motivate and create nurses' awareness of technology to achieve the patient safety goals, centered care, and job satisfaction.

\section{Acknowledgment}

This study was supported by the Ministry of Education, Culture, Study and Technology of the Republic of Indonesia (no.NKB-299/UN2.RST/ HKP.05.00/2021). In addition, the authors are grateful to the Directorate of Study and Development, Universitas
Indonesia

\section{Authors' Contributions}

Setyowati contributed to the study, design, data analysis, manuscript writing.

Hanny Handiyani contributed to the study, data collection, data analysis, manuscript writing.

Raldi Artono Koestoer contributed to the study, data analysis, manuscript writing.

Diah Arruum contributed to the study through data collection and manuscript writing.

\section{References}

1. Gartner. How to Succeed in Healthcare Digital Transformation; 2018. Available from: https://www.gartner. com/smarterwithgartner/how-to-succeed-in-healthcare-digitaltransformation [Last accessed on 2021 Nov 30].

2. McKinsey. McKinsey on Healthcare: Best of 2019. McKinsey Co.; 2019. Available from: https://www.mckinsey.com/industries/ healthcare-systems-and-services/our-insights/mckinsey-onhealthcare-best-of-2019\#. [Last accessed on 2021 Oct 17].

3. Taylor R, Bower A, Girosi F, Bigelow J, Fonkych K, Hillestad R. Promoting health information technology: Is there a case for more-aggressive government action? Health Aff (Millwood). 2005;24(5):1234-45. https://doi.org/10.1377/hlthaff.24.5.1234 PMid: 16162568

4. Catan G, Espanha R, Veloso Mendes R, Toren O, Chinitz D. The impact of eHealth and mHealth on doctor behavior and patient involvement: An Israeli and Portuguese comparative approach. Stud Health Technol Inform. 2015;210:813-7.

PMid:25991267

5. Rouleau G, Gagnon MP, Côté J, Payne-Gagnon J, Hudson E, Dubois CA. Impact of information and communication technologies on nursing care: Results of an overview of systematic reviews. J Med Internet Res. 2017;19(4):e122. https://doi.org/10.2196/jmir.6686

PMid:28442454

6. Tunlind A, Granström J, Engström A. Nursing care in a hightechnological environment: Experiences of critical care nurses. Intensive Crit Care Nurs. 2015;31(2):116-23. https://doi. org/10.1016/j.iccn.2014.07.005 PMid:25442241

7. Kiekkas P, Karga M, Poulopoulou M, Karpouhtsi I, Papadoulas V, KoutsojannisC.Useoftechnologicalequipmentincriticalcareunits: Nurses' perceptions in Greece. J Clin Nurs. 2006;15(2):178-87. https://doi.org/10.1111/j.1365-2702.2006.01243.x PMid: 16422735

8. Shanafelt TD, West CP, Sinsky C, Trockel M, Tutty M, Satele DV, et al. Changes in burnout and satisfaction with work-life integration in physicians and the general US working population between 2011 and 2017. Mayo Clin Proc. 2019;94(9):1681-94. https://doi.org/10.1016/j.mayocp.2018.10.023

PMid:30803733 
9. Dyrbye LN, Shanafelt TD, Sinsky CA, Cipriano PF, Bhatt J, Ommaya $A$, et al. Burnout among health care professionals: A call to explore and address this underrecognized threat to safe, high-quality care. NAM Perspect. 2017;7(7):1-11.

10. McHugh MD, Kutney-Lee A, Cimiotti JP, Sloane DM, Aiken LH. Nurses' widespread job dissatisfaction, burnout, and frustration with health benefits signal problems for patient care. Health Aff (Millwood). 2011;30(2):202-10. https://doi.org/10.1377/ hlthaff.2010.0100

PMid:21289340

11. White EM, Aiken LH, McHugh MD. Registered nurse burnout, job dissatisfaction, and missed care in nursing homes. J Am Geriatr Soc. 2019;67(10):2065-71. https://doi.org/10.1111/ jgs. 16051

\section{PMid:31334567}

12. Cimiotti JP, Aiken LH, Sloane DM, Wu ES. Nurse staffing, burnout, and health care-associated infection. NIH Public Access. 2012;40(6):1-13.

13. Rushton $\mathrm{CH}$, Batcheller J, Schroeder K, Donohue P. Burnout and resilience among nurses practicing in high-intensity settings. Health Work Environ. 2015;24(5):412-20. https://doi. org/10.4037/ajcc2015291

PMid:26330434

14. Woodhead EL, Northrop L, Edelstein B. Stress, social support, and burnout among long-term care nursing staff. J Appl Gerontol. 2014;35(1):1-22.

15. Redeker NS. Sensor technology for nursing research. Nurs Outlook. 2020;68(6):711-9. https://doi.org/10.1016/j. outlook.2020.03.009 PMid:32580871

16. Iqbal FM, Joshi M, Khan S, Ashrafian H, Darzi A. Implementation of wearable sensors and digital alerting systems in secondary care: Protocol for a real-world prospective study evaluating clinical outcomes. JMIR Res Protoc. 2021;10(5):1-5. https://doi. org/10.2196/26240

PMid:33944790

17. Gance-Cleveland B, McDonald CC, Walker RK. Use of theory to guide development and application of sensor technologies in Nursing. Nurs Outlook. 2020;68(6):698-710. https://doi. org/10.1016/j.outlook.2020.04.007

\section{PMid:32620271}

18. Nakano $\mathrm{Y}$, Yokotani $\mathrm{T}$, Betriana $\mathrm{F}$, Kawai $\mathrm{C}$, Ito $\mathrm{H}$. Perceptions of nurse managers and staff nurses regarding technological competency as caring in nursing theory in general hospitals in Japan. Belitung Nurs J. 2021;7(6):467-75. http://doi. org/10.33546/bnj. 1767

19. Seibert K, Domhoff D, Huter K, Krick T, Rothgang H, WolfOstermann K. Application of digital technologies in nursing practice: Results of a mixed methods study on nurses' experiences, needs and perspectives. Z Evid Fortbild Qual Gesundhwes. 2020;158-159:94-106. https://doi.org/10.1016/j. zefq.2020.10.010

PMid:33223491

20. Fadel MA, Elfallah EA, Elghriani A. An evaluation of the attitudes of healthcare nurses towards new technologies. In: ACM International Conference Proceedings Series; 2020. p. 1-6.

21. Bail K, Davey R, Currie M, Gibson J, Merrick E, Redley B. Implementation pilot of a novel electronic bedside nursing chart: A mixed-methods case study. Aust Health Rev. 2020;44(5):672-6. https://doi.org/10.1071/AH18231 PMid:32933642

22. Leenen JP, Dijkman EM, van Dijk JD, van Westreenen $\mathrm{HL}$, Kalkman C, Schoonhoven L, et al. Feasibility of continuous monitoring of vital signs in surgical patients on a general ward: An observational cohort study. BMJ Open. 2021;11(2):e042735. https://doi.org/10.1136/bmjopen-2020-042735

PMid:33597138

23. Ngugi PN, Were MC, Babic A. Users 'perception on factors contributing to electronic medical records systems use: A focus group discussion study in healthcare facilities setting in Kenya. BMC Med Inform Decis Mak. 2021;21(362):1-14. https://doi. org/10.1186/s12911-021-01737-x

24. Bisrat A, Minda D, Assamnew B, Abebe B, Abegaz T. Implementation challenges and perception of care providers on electronic medical records at St. Paul's and Ayder hospitals, Ethiopia. BMC Med Inform Decis Mak. 2021;21(1):306. https:// doi.org/10.1186/s12911-021-01670-z

PMid:34727948

25. Weenk M, Bredie SJ, Koeneman M, Hesselink G, van Goor H, van de Belt TH. Continuous monitoring of vital signs in the general ward using wearable devices: Randomized controlled trial. J Med Internet Res. 2020;22(6):e15471. https://doi. org/10.2196/15471

PMid:32519972

26. Burkoski V, Yoon J, Hutchinson D, Solomon S, Collins BE Experiences of nurses working in a fully digital hospital: A phenomenological study. Can J Nurs Leadersh. 2019;32:1-16.

27. De Leeuw JA, Woltjer H, Kool RB. Identification of factors influencing the adoption of health information technology by nurses who are digitally lagging: In-depth interview study. J Med Internet Res. 2020;22(8):e15630. https://doi.org/10.2196/15630 PMid:32663142

28. Jahnke I, Riedel N, Popescu M, Skubic M, Rantz M. Social practices of nurse care coordination using sensor technologieschallenges with an alert system adoption in assisted living communities for older adults. Int J Nurs Sci. 2021;8(3):289-97. https://doi.org/10.1016/j.ijnss.2021.05.011

PMid:34307777

29. Melnick ER, West CP, Nath B, Cipriano PF, Peterson C Satele DV, et al. The association between perceived electronic health record usability and professional burnout among US nurses. J Am Med Inform Assoc. 2021;28(8):1632-41. https:// doi.org/10.1093/jamia/ocab059

PMid:33871018

30. Mather C, Cummings E, Gale F. Nurses as stakeholders in the adoption of mobile technology in australian health care environments: Interview study. JMIR Nurs. 2019;2:e14279. https://doi.org/10.2196/14279

PMid:34345771

31. Moll J, Cajander A. On patient accessible electronic health records and the experienced effect on the work environment of nurses. Stud Health Technol Inform. 2020;270:1021-5. https:// doi.org/10.3233/SHTI200316 PMid:32570536

32. Liu $\mathrm{Y}$, Aungsuroch $\mathrm{Y}$, Yunibhand J. Job satisfaction in nursing: A concept analysis study. Int Nurs Rev. 2016;63(1):84-91. https://doi.org/10.1111/inr.12215 PMid:26492403

33. George E, Zakkariya KA. Psychological Empowerment and Job Satisfaction in the Banking Sector. Psychological Empowerment and Job Satisfaction in the Banking Sector. Berlin, Germany: Springer; 2018. p. 1-184.

34. Bolli T, Pusterla F. Decomposing the Effects of Digitalization on Workers' Job Satisfaction. Zurich: ETH; 2021. p. 1-37.

35. Dewsbury G. Use of information and communication technology in nursing services. Br J Community Nurs. 2019;24(12):604-7. https://doi.org/10.12968/bjcn.2019.24.12.604 PMid:31800320

36. Orhan I, Serin EK. Use of health technologies by nurses and their thoughts on technology. Int J Caring Sci. 2019;12(1):416-22. 
37. Vainieri M, Seghieri C, Barchielli C. Influences over Italian nurses' job satisfaction and willingness to recommend their workplace. Health Serv Manag Res. 2021;34(2):62-9. https:// doi.org/10.1177/0951484820943596

PMid:32731767

38. do Adro FJ, Leitão JC. Leadership and organizational innovation in the third sector: A systematic literature review. Int J Innov Stud. 2020;4(2):51-67

39. Wati NM, Lestari RT, Ayuningtyas G, Ardi NB, Juanamasta IG. Nurse perceived of caring leadership: A qualitative descriptive study. Open Access Maced J Med Sci. 2021;9:88-93.

40. Riana IG, Suparna G, Gusti Made I, Kot S, Rajiani I. Human resource management in promoting innovation and organizational performance. Probl Perspect Manag. 2020;18(1):107-18.

41. Putriyadi DE, Puspa T, Tanuwijaya J. The Effect of job satisfaction, management innovation, and organizational motivation on organizational performance. In: Advance in Economics, Business and Management Research; 2020. p. 50-3.

42. Krick T, Huter K, Domhoff D, Schmidt A, Rothgang H, WolfOstermann K. Digital technology and nursing care: A scoping review on acceptance, effectiveness and efficiency studies of informal and formal care technologies. BMC Health Serv Res. 2019;19(1):400. https://doi.org/10.1186/s12913-019-4238-3

PMid:31221133 